\title{
Pengaruh model pembelajaran learning cycle 5e yang dipadu think pair share terhadap hasil belajar kognitif siswa kelas XI SMA Negeri Sidoarjo pada materi larutan penyangga
}

\author{
S. Luluk AN Nisak M, Fauziatul Fajaroh*, Siti Marfu'ah \\ Universitas Negeri Malang, Jl. Semarang No. 5 Malang, Jawa Timur, Indonesia \\ *Penulis korespondensi, Surel: fauziatul.fajaroh.fmipa@um.ac.id
}

Paper received: 01-06-2021; revised: 15-06-2021; accepted: 30-06-2021

\begin{abstract}
It is crucial that the concepts of buffer solutions must be properly understood by students. It is due to the fact that buffer solutions are closely related to daily life, for example in blood, drugs, and others. The results of research and interviews show that students' understanding and student learning outcomes about the buffer solution material is still low. A student-centered learning process is needed so that it can make the learning process more fun and improve students' learning outcomes. A meaningful student-centered learning is needed for the Learning Cycle (LC) learning model. However, the group discussion on the 5E LC learning model was less patterned, so it was combined with a patterned cooperative learning model that is Think-Pair-Share (TPS). This study aims to see the implementation of the learning process from the classroom with 5E LC -TPS and 5E LC learning models, and the influence of the 5E LC-TPS on cognitive learning outcomes from the eleventh grade students of Sidoarjo on buffer solution material. The design of the study used in this study is a quasi-experimental design with post-test-only-control group design. The research finding showed that: (1) the implementation of the learning process of the two categorized classes was done very well that is 98.3 percent in the experimental class and 95.4 percent in the control class, (2) there is the influence of the 5E LC learning model combined by TPS on the cognitive learning outcomes of class students as indicated by the significant average differences of the two classes. The average value of cognitive learning outcomes of experimental class students is higher than the control class which is equal to 85.43 and the control class is 81.62 . From the results of these studies it can be concluded that there is the influence of the 5E LC-TPS learning model on improving students' cognitive learning outcomes.
\end{abstract}

Keywords: 5E Learning Cycle combined by Think Pair Share; Cognitive Learning Outcome; Buffer Solution

\begin{abstract}
Abstrak
Konsep-konsep larutan penyangga perlu dipahami siswa karena larutan penyangga erat kaitannya dengan kehidupan sehari-hari, misalnya penyangga karbonat dalam darah, obat-obatan, dan lainlain. Hasil penelitian dan wawancara menunjukkan bahwa pemahaman siswa dan hasil belajar siswa tentang materi larutan penyangga masih rendah. Diperlukan suatu proses pembelajaran yang berpusat pada siswa sehingga dapat menjadikan proses pembelajaran lebih bermakana dan meningkatkan hasil belajar siswa. Salah satu pembelajaran bermakna yang berpusat pada siswa adalah model pembelajaran Learning Cycle (LC). Namun, diskusi kelompok pada model pembelajaran $L C 5 E$ kurang berpola, sehingga dipadukan dengan model pembelajaran kooperatif yang berpola yaitu Think Pair Share (TPS). Penelitian ini bertujuan untuk melihat keterlaksanaan proses pembelajaran dari kelas dengan model pembelajaran $L C$ 5E-TPS dan $L C 5 E$ serta pengaruh model pembelajaran $L C 5 E$-TPS terhadap hasil belajar kognitif siswa kelas XI SMA Negeri Sidoarjo pada materi larutan penyangga. Rancangan Penelitian yang digunakan dalam penelitian ini adalah rancangan eksperimental semu dengan post-test-only-control group design. Hasil penelitian menunjukkan bahwa: (1) keterlaksanaan proses pembelajaran kedua kelas terkategori terlaksana dengan sangat baik, yaitu 92,11 persen pada kelas eksperimen dan 90,78 persen pada kelas kontrol. (2) ada pengaruh model pembelajaran $L C 5 E$ yang dipadu TPS terhadap hasil belajar kognitif siswa kelas yang ditunjukkan oleh perbedaan rata-rata yang signifikan dari kedua kelas. Nilai rata-rata hasil belajar kognitif siswa kelas eksperimen lebih tinggi dari pada kelas kontrol
\end{abstract}


yaitu sebesar 85,43 dan kelas kontrol sebesar 81,62. Dari hasil penelitian tersebut dapat disimpulkan bahwa ada pengaruh model pembelajaran $L C$ 5E-TPS terhadap peningkatan hasil belajar kognitif siswa.

Kata kunci: Learning Cycle 5E yang dipadu Think Pair Share; hasil belajar kognitif; larutan penyangga

\section{Pendahuluan}

Konsep-konsep larutan penyangga perlu dipahami siswa, karena larutan penyangga erat kaitannya dengan kehidupan sehari-hari, misalnya dalam darah, obat-obatan, dan lainlain. Hasil penelitian Alighiri, et. al (2018) menunjukkan bahwa dengan pembelajaran ekspositori hanya $45,53 \%$ siswa yang paham tentang konsep larutan penyangga. Penelitian dari Nurhidayatullah, et al (2018) menunjukkan bahwa dengan pembelajaran metode ceramah siswa yang paham konsep larutan penyangga hanya sebesar 37\%. Fakta tersebut menunjukkan bahwa dengan pembelajaran tersebut, pemahaman konsep siswa pada larutan penyangga masih rendah.

Berdasarkan kenyataan tersebut, diperlukan suatu upaya perbaikan proses pembelajaran untuk meningkatkan hasil belajar siswa pada materi larutan penyangga. Diperlukan suatu proses pembelajaran yang berpusat pada siswa sehingga dapat menjadikan proses pembelajaran lebih bermakana. Pembelajaran bermakna menuntut siswa untuk aktif berpikir dalam proses pembelajaran, selain itu siswa juga dituntut untuk dapat menghubungkan pengetahuan atau konsep yang telah dipelajari dengan konsep larutan penyangga yang sedang dipelajari. Salah satu pembelajaran bermakna yang berpusat pada siswa adalah model pembelajaran Learning Cycle (LC) (Iskandar, 2011). Model pembelajaran $L C$ memiliki beberapa jenis berdasarkan fasenya, pada penelitian ini digunakan model pembelajaran $L C 5 E$. Hasil penelitian sebelumnya menunjukkan bahwa $L C 5 E$ dapat meningkatkan hasil belajar siswa (Aprilia, 2012), pemahaman konsep ilmiah siswa (Jack, 2017) dan kemampuan berpikir kritis siswa (Arini, et. al, 2017). Dari hasil penelitianpenelitian tersebut, model pembelajaran $L C 5 E$ diharapkan dapat diterapkan pada materi larutan penyangga.

Namun, diskusi kelompok pada model pembelajaran $L C 5 E$ kurang berpola, sehingga diskusi kurang terarah dengan baik. Hal tersebut memungkinkan terdapat anggota yang tidak ikut berdiskusi, sehingga tidak dapat mengkonstruk pemahamannya dengan baik. Oleh karena itu, dibutuhkan model pembelajaran kooperatif yang berpola untuk dapat memaksimalkan proses diskusi pada pembelajaran $L C 5 E$. Salah satu model pembelajaran kooperatif yang berpola adalah TPS. Model pembelajaran TPS memiliki keunggulan yaitu dapat mengoptimalkan partisipasi siswa, memberi kesempatan siswa untuk bekerja sendiri dan bekerja sama dengan orang lain (Fajaryanti, et. al., 2014). Beberapa penelitian menunjukkan bahwa memadukan model pembelajaran $L C 5 E$ dengan pembelajaran kooperatif lebih efektif dan meningkatkan hasil belajar kognitif siswa (Trisnawati, 2013; Fasilah, 2016). Sehingga penelitian ini bertujuan untuk melihat keterlaksanaan proses pembelajaran dari kelas dengan model pembelajaran LC 5E-TPS dan LC $5 E$ serta pengaruh model pembelajaran $L C 5 E$-TPS terhadap hasil belajar kognitif siswa kelas XI SMA Negeri Sidoarjo pada materi larutan penyangga. 


\section{Metode}

Rancangan Penelitian yang digunakan dalam penelitian ini adalah rancangan eksperimental semu dengan post-test-only-control group design. Pemilihan kelas eksperimen dan kelas kontrol dilakukan dengan teknik purposive sampling. Sampel penelitian adalah kelas XI MIA 3 yang terdiri dari 35 siswa sebagai kelas eksperimen (LC5E-TPS), dan kelas MIA 5 yang terdiri dari 34 siswa sebagai kelas kontrol ( $L C 5 E$ ). Instrumen perlakuan yang digunakan adalah Silabus, RPP dan LKS dengan hasil validasi dari 2 orang guru kimia yang terkategori baik. Instrumen pengukuran yang digunakan adalah 20 butir soal pilihan ganda yang valid dengan nilai reliabilitas sebesar 0,84 . Data keterlaksanaan pembelajaran dianalisis menggunakan analisis deskriptif, sedangkan data hasil belajar kognitif siswa dilakukan uji hipotesis dengan statistik nonparametrik yaitu uji Mann Whitney dengan bantuan program SPSS 15.0 for Windows.

\section{Hasil dan Pembahasan}

Data hasil keterlaksanaan pembelajaran diperoleh dari 2 observer yang dihitung rataratanya dan dihitung persentasenya. Persentase data keterlaksanaan pembelajaran dapat dilihat pada Tabel 1.

Tabel 1 Persentase Rata-rata Keterlaksanaan Pembelajaran

\begin{tabular}{|c|c|c|c|c|c|c|}
\hline \multirow{3}{*}{ Pertemuan } & \multicolumn{6}{|c|}{ Keterlaksanaan Pembelajaran } \\
\hline & \multicolumn{3}{|c|}{ Kelas LC 5E (Kontrol) } & \multicolumn{3}{|c|}{ Kelas $L C 5 E-T P S$ (Eksperimen) } \\
\hline & Observer I & Observer II & $\begin{array}{l}\text { Rata- } \\
\text { rata }\end{array}$ & Observer I & Observer II & $\begin{array}{l}\text { Rata- } \\
\text { rata }\end{array}$ \\
\hline Pertemuan 1 & $82,75 \%$ & $82,75 \%$ & $82,75 \%$ & $87,09 \%$ & $87,09 \%$ & $87,09 \%$ \\
\hline Pertemuan 2 & $88,46 \%$ & $92,30 \%$ & $90,38 \%$ & $93,10 \%$ & $89,65 \%$ & $91,37 \%$ \\
\hline Pertemuan 3 & $92,00 \%$ & $88,00 \%$ & $90,00 \%$ & $88,00 \%$ & $92,00 \%$ & $90,00 \%$ \\
\hline Pertemuan 4 & $100,00 \%$ & $100,00 \%$ & $100,00 \%$ & $100,00 \%$ & $100,00 \%$ & $100,00 \%$ \\
\hline $\begin{array}{l}\text { Rata-rata } \\
\text { akhir }\end{array}$ & & $90,78 \%$ & & & $92,11 \%$ & \\
\hline
\end{tabular}

Uji prasyarat data hasil belajar kognitif siswa dihasilkan data yang tidak normal dan memiliki varian yang homogen sehingga digunakan uji statistik non parametrik yang digunakan untuk uji hipotesis data hasil belajar kognitif siswa adalah uji Mann Whitney. Uraian hasil uji Mann Whitney dapat dilihat pada Tabel 2.

Tabel 2. Hasil Uji Mann Whitney Data Hasil Belajar Kognitif Siswa

\begin{tabular}{llll}
\hline Kelas & Nilai Rata-rata & Nilai Signifikan & Kesimpulan \\
\hline $\begin{array}{l}\text { Kontrol } \\
\text { Eksperimen }\end{array}$ & 81,62 & 0,01 & $\begin{array}{l}\text { Ada Perbedaan hasil } \\
\text { belajar kognitif siswa }\end{array}$ \\
\hline
\end{tabular}

Dari hasil uji Mann Whitney diperoleh signifikansi 0,01 yang menunjukkan bahwa signifikansi tersebut $<0,05$ sehingga dapat diambil kesimpulan ada perbedaan hasil belajar kognitif yang signifikan antara siswa kelas kontrol yang dibelajarkan dengan model pembelajaran $L C 5 E$ dengan siswa kelas eksperimen yang dibelajarkan dengan model pembelajaran $L C$ 5E-TPS. 
Hasil penelitian menunjukkan bahwa: (1) keterlaksanaan proses pembelajaran kedua kelas terkategori terlaksana dengan sangat baik, yaitu 92,11\% pada kelas eksperimen dan 90,78\% pada kelas kontrol. (2) ada pengaruh model pembelajaran LC 5E - TPS terhadap hasil belajar kognitif siswa kelas yang ditunjukkan oleh perbedaan rata-rata yang signifikan dari kedua kelas. Nilai rata-rata hasil belajar kognitif siswa kelas eksperimen lebih tinggi dari pada kelas kontrol yaitu sebesar 85,43 dan kelas kontrol sebesar 81,62. Dari hasil penelitian tersebut dapat disimpulkan bahwa ada pengaruh model pembelajaran LC 5E-TPS terhadap peningkatan hasil belajar kognitif siswa.

\section{Simpulan}

Beberapa kesimpulan dari hasil penelitian yang telah diuraikan adalah sebagai berikut:

1. Proses pembelajaran dari kedua kelas selama empat kali pertemuan termasuk dalam kategori terlaksana dengan sangat baik. Dengan persentase rata-rata keterlaksanaan proses pembelajaran $L C 5 E$ sebesar $90,78 \%$ dan persentase rata-rata keterlaksanaan proses pembelajaran $L C$ 5E-TPS sebesar 92,11\%.

2. Terdapat perbedaan hasil belajar kognitif siswa kedua kelas pada materi Larutan Penyangga. Rata-rata hasil belajar kognitif siswa yang dibelajarkan dengan $L C 5 E$ - TPS lebih tinggi yakni sebesar 85,43 dari pada siswa yang dibelajarkan dengan $L C 5 E$ sebesar 81,62. Sehingga dapat disimpulkan terdapat pengaruh hasil belajar kognitif siswa yang dibelajarkan dengan $L C 5 E$-TPS.

\section{Ucapan Terima Kasih (Opsional)}

Ucapan terimakasih kepada Ibu Dr. Hj. Fauziatul Fajaroh, M.S. dan Dr. Siti Marfu'ah, M.S. yang telah membimbing penulis selama melakukan penelitian dan penulisaan artikel. Kepala sekolah, guru kimia dan guru SMA Negeri Sidoarjo yang telah membantu penulis selama penelitian dan pengambilan data. Siswa kelas XI IPA 3 dan XI IPA 5 SMA Negeri Sidoarjo yang telah menjadi subjek penelitian.

\section{Daftar Rujukan}

Alighiri, D., Drastisianti, A., \& Susilaningsih, E. (2018). Pemahaman konsep siswa materi larutan penyangga dalam pembelajaran multiple representasi. Jurnal Inovasi Pendidikan Kimia, 12(2).

Arini, S., Haryono, H., \& Saputro, S. (2017). Upaya peningkatan kemampuan berpikir kritis dan prestasi belajar siswa dengan menggunakan model pembelajaran learning cycle $5 \mathrm{E}$ pada materi pokok hidrolisis garam kelas XI MIA 1 SMA Negeri 1 Banyudono semester genap tahun pelajaran 2015/2016. Jurnal Pendidikan Kimia, 6(2), 161-170.

Fajaryanti, D. E., Tiwow, V. M., \& Rahman, N. (2014). Penggunaan model pembelajaran kooperatif tipe thinkpair-share (TPS) pada pokok bahasan struktur atom untuk meningkatkan hasil belajar siswa kelas X SMA Negeri 2 Palu. Jurnal Akademika Kimia, 3(3), 129-134.

Iskandar, S. M. (2011). Pendekatan pembelajaran sains berbasis konstruktivis. Malang: Bayumedia Publishing.

Jack, G. U. (2017). The effect of learning cycle constructivist-based approach on students academic achievement and attitude towards chemistry in secondary schools in north-eastern part of Nigeria. Educational Research and Reviews, 12(7), 456-466.

Nurhidayatulah, N., \& Prodjosantoso, A. K. (2018). Miskonsepsi materi larutan penyangga. Jurnal Inovasi Pendidikan IPA, 4(1), 41-51. 